\title{
ROLE PLAYING LEARNING METHOD IN THE SUBJECT OF AQIDAH AKHLAK AT MADRASA
}

\author{
Firman Mansir \\ Universitas Muhammadiyah Yogyakarta, Indonesia \\ firmanmansir@umy.ac.id \\ Tumin \\ Universitas Muhammadiyah Yogyakarta, Indonesia \\ tumin@umy.ac.id \\ Halim Purnomo \\ Universitas Muhammadiyah Yogyakarta, Indonesia \\ halimpurnomo@umy.ac.id
}

\begin{abstract}
This research describes and discusses about the importance of using role-playing method in Aqidah Akblak at Madrasa. Professional teachers are those who are able to lead students to achieve maximum outcomes. This research aims to realize the learning of Aqidah Akblak that is appropriate to the current context. Thus, teachers are required to use brilliant and different methods from the others. Aqidah Akblak subject requires an effective method because Aqidah Akhlak has different characteristics from other subjects. That is why $21^{\text {st }}$ century PAI (Islamic education) teachers need to be creative by utilizing a variety of learning methods. An effective method for Aqidah Akblak subjects is role playing. The skills of a PAI teacher are expected to emerge from the role playing method in the Aqidah Akblak learning process. The strategy and method of role playing are one of the components contained in the learning system. The components are capable of delivering effective and dynamic learning processes. Therefore, from various learning methods used by PAI teachers, role playing one is considered effective to make directed, capable, and effective learning based on learning goals.
\end{abstract}

Keywords: Learning, Role Playing, Aqidah Akhlak and Madrasa.

\section{Abstrak}

Penelitian ini mengkaji tentang pentingnya penggunaan metode role playing dalam pembelajaran Aqidah Akblak di madrasah aliyah. Pendidik yang baik. yaitu pendidik yang mampu mengantarkan peserta didik untuk. mencapai basil yang baik bahan sempurna sesuai dengan tujuan pendidikan. Tujuan penelitian ini adalah untuk mencapai keefektifan pembelajaran yang sudah tentu dibutubkan pendidik atau guru yang profesional yang benar-benar memahami tentang bagaimana melakukan pembelajaran yang baik, selain itu para pendidik tentu mempunyai keterampilan mengajar yang baik sebelum mengemban tugas sebagai pendidik. Keterampilan seorang pendidik. itu di dapatkan dari pelatihan pengalaman belajar. Strategi atau metode pengajaran merupakan salah satu komponen yang terdapat dalam sistem pembelajaran, komponenkomponen yang terdapat itu adalah: tujuan pembelajaran, materi ajar, peserta didik, waktu dan pendidik. Dalam sistem pengajaran terdapat beberapa metode diantaranya: ceramah, diskusi dan masih banyak lagi, semua itu merupakan syarat tercapainya tujuan pembelajaran dan tercapainya keberhasilan pendidikan, selain itu syarat penting lainnya materi pembelajaran dan setrategi pembelajaran.

Kata Kunci: Pembelajaran, Role Playing, Aqidah Akblak dan Madrasah 


\section{INTRODUCTION}

In the field of education, there is always discussion on the learning process and experience. Learning is a reciprocity and interaction process between teachers and students and also collaborates with other equally supportive components in its process. ${ }^{1}$ The learning process is the phase through which a learning activity in class is performed. Learning requires suitable methods for teachers to use in teaching their students. The learning method is a means of conveying a lesson that is arranged systematically and has particular objectives to accomplish the objectives of the lesson. Therefore, with the learning method, students can interpret and understand so that they can solve problems relevant to the material presented.

Typically, in learning, teachers utilise various methods such as the lecture method. This method is then always utilised by the teacher in the delivery of learning, information, even though there is little interaction. With this lecture method, the interaction of educators and students occurs during the learning process ${ }^{2}$. The lecture method is an interaction carried out through verbal and hearing which is explained by educators and listened to by students, or in other words, students are only as loyal listeners ${ }^{3}$. The lecture method is the method used most often by teachers since a long time ago, or in other words, this method is a traditional one. Besides, the teacher only explains, conveys, and describes the lesson without other practice or learning style, making this method relies on the creativity of the teachers, including ways for students to not be bored. ${ }^{4}$

The benefits of the lecture method are that when this method is applied, educators will usually add aids in the form of audiovisual equipment such as questions and answers, demonstrations, and much more. Besides, by using this method, educators and students can make eye contact. With eye contact, the teachers can find out which students really pay attention or not, and eye contact makes students feel cared for. Another advantage of the lecture method is that educators or teachers can use language that is easily understood by students. Further, the teachers can also use terms appropriately based on the level being taught. $^{5}$

The use of the lecture method has another advantage that educators can master the class, whether it is a small or even a large class because most audiences use hearing. Besides, this method allows the teachers or educators to master the class and can also explain the lesson well ${ }^{6}$. The shortage of the lecture method is that in this method, usually, the students'

1 Purba, F. J. Meningkatkan Hasil Belajar Siswa Dengan Metode Demonstrasi. INPAFI (Inovasi Pembelajaran Fisikea), 6 (3), 83-91. https://doi.org/10.24114/inpafi.v6i3.11115, 2018.

2 Mahmudah, M. Urgensi Diantara Dualisme Metode Pembelajaran Ceramah Dalam Kegiatan Belajar Mengajar Untuk Siswa MI/SD. Cakrawala: Jurnal Studi Islam, 11(1), 116-129. https://doi.org/10.31603/cakrawala.v11i1.107, 2016.

${ }^{3}$ Rem, P. S. Perbedaan Hasil Belajar Antara Metode Ceramah Konvensional Dengan Ceramah Berbantuan Media Animasi Pada Pembelajaran Kompetensi Perakitan Dan Pemasangan Sistem Rem. Jurnal Pendidikan Teknik Mesin, 9(2), 2009.

${ }^{4}$ Yasir, M., \& Karlina, E. Pengaruh Model Pembelajaran Stad Terhadap Hasil Belajar Mata Pelajaran Akuntansi. Research and Development Journal Of Education ISSN : 2406-9744, 2(1), 53-65, 2015.

5 Mahmudah, M. Urgensi Diantara Dualisme Metode Pembelajaran Ceramah Dalam Kegiatan Belajar Mengajar Untuk Siswa MI/SD. Cakrawala: Jurnal Studi Islam, 11(1), 116-129. https://doi.org/10.31603/cakrawala.v11i1.107, 2016.

6 Yasir, M., \& Karlina, E. Pengaruh Model Pembelajaran Stad Terhadap Hasil Belajar Mata Pelajaran 
understanding depends on what the teachers say. Therefore, if the teachers convey incomplete or insufficient explanation, inevitably, the students' understanding will also be less or incomplete. The weakness of the lecture method is commonly the use of words that are less varied or in other words monotonous. As a result, students become bored and passive since they only listen. Therefore, this method should be used for certain subjects and is less appropriate if used in all subjects, especially in the field of Islamic Religious Education ${ }^{8}$.

Role-Playing methods have many types, but all of these methods cannot be applied in all subjects, only a few suitable methods are utilised. Nowadays, teachers must be clever in finding and choosing the suitable learning methods for teaching the material to be delivered, and the teachers must be creative in presenting the material so that students do not feel bored and can comprehend the material presented. One of the learning methods used by teachers is role playing. This method uses a role system, which is portraying daily behaviour in the material presented. This method can assist students to understand an event so that they can respond to it, foster their self-creativity, and can understand the attitudes of others in interpreting the events.

In teaching and learning activities, the teacher's role as a guide is to provide instructions when needed ${ }^{9}$. Over time, the utilisation of this learning method has several obstacles, such as when the RPP has written the Role-Playing method, but in fact, teachers use other methods or even apply the lecture method continuously. Therefore, the thing that should be pointed out is that the teachers lack understanding of the learning methods that they will run, where initially wanting to create a varied atmosphere, actually makes students less conducive and bored. Therefore, based on the description above, research on Role-Playing learning methods is useful for explaining and describing this method in detail and applying it to the subjects of Aqidah Akhlak.

\section{METHOD}

This research was a qualitative type carried out by collecting data through literature. The data was obtained from several primary references, both primary and secondary data. The primary data include articles and scientific papers on the Role-Playing method. Meanwhile, secondary data obtained from various studies that have been conducted, including from various books, theses, and opinion writings associated with the research object. Data collection methods were conducted by collecting various books, articles, journals that studies the Role-Playing learning method. Once the data was collected, then a sorting was carried out regarding the books, journals and articles that discuss the method of role playing. Subsequently, it was analysed deductively and inductively. The deductive method was used to obtain an overview of the role-playing method in detail. Meanwhile, the inductive method was

\footnotetext{
Akuntansi. Research and Development Journal Of Education ISSN : 2406-9744, 2(1), 53-65, 2015.

7 Mahmudah, M. Urgensi Diantara Dualisme Metode Pembelajaran Ceramah Dalam Kegiatan Belajar Mengajar Untuk Siswa MI/SD. Cakrawala: Jurnal Studi Islam, 11(1), 116-129. https://doi.org/10.31603/cakrawala.v11i1.107, 2016.

${ }^{8}$ Yasir, M., \& Karlina, E. Pengaruh Model Pembelajaran Stad Terhadap Hasil Belajar Mata Pelajaran Akuntansi. Research and Development Journal Of Education ISSN : 2406-9744, 2(1), 53-65, 2015.

9 Mansir, F., Purnomo, H., \& Tumin. T. Penerapan Pembelajaran Pendidikan Agama Islam Berbasis Sains Budaya Lokal di Sekolah dan Madrasah. TARBAWY: Indonesian Journal of Islamic Education, 7(1), 70-79, 2020.
} 
used to obtain and express a picture of the role-playing method as a whole. Data analysis was a means to process the data obtained during the study conducted so that a conclusion can be drawn.

\section{DISCUSSION}

Aqidah Akblak are one of the most significant religious subjects for every student to learn. These subjects' objective is that students can have good faith and amaliyah according to the guidance of the Islamic Religion. In this case, it is the task of the teachers to help achieve the objectives by conveying the material. Therefore, it can be well understood and practised in everyday life and for their provisions in the hereafter. Thus, a science which in broad terms means knowledge includes humanities and scientific knowledge ${ }^{10}$.

In this case, in the realm of classes in all institutions, maybe in conveying learning, the way used by teachers are very different. The way to convey must also be able to melt the situation so that students are not bored with what is conveyed by their educators. It is sometimes not yet mastered by the teacher, as they are still awkward with the students, making this also a problem for the teachers' personality. Therefore, in education, there is what is considered teacher competency, which implied the ability that must be possessed by a teacher in conducting the teaching and learning process in class.

An example of a method often used is the lecture method. This method is very simple for teachers since they only need to convey important points in front of their students. However, the teachers must also master the lesson too so that the class situation is not too bored. Sometimes, students who receive the lecture method may experience boredom since the teachers explain the material too deep. Many also assume that the lecture method is the cause of the low learning interest of students. However, it cannot be justified entirely because it has nothing to do with learning. Everything is also back to the educators, depending on how they use the lecture method.

The lecture method is also referred to as a highly classical learning method. As we look back on Indonesia's history, the first president, Soekarno, was famous as the Asian stage lion since he delivered his learning speech using the lecture method. He delivered it very loudly, making the audience amazed with what was conveyed by Bung Karno. That is the reason why it is not surprising that this method makes people dare to express their aspirations in front of many people ${ }^{11}$.

However, in the utilisation of this lecture method, there may be advantages and disadvantages. The advantages of the lecture method include: a) The teachers are easy to master the class. Indeed, when teachers teach using the lecture method, regarding the situation in the classroom, teachers are racing in the material delivered to their students. It shows that the teachers do not only focus on the method but they also need to pay attention to their

10 Mansir, F. Diskursus Sains dalam Kurikulum Pendidikan Agama Islam di Sekolah dan Madrasah Era Digital. Kamaya: Jurnal Ilmu Agama, 3(2), 144-157, 2020.

11 Harsono, B. Perbedaan Hasil Belajar Antara Metode Ceramah Konvensional Dengan Ceramah Berbantuan Media Animasi Pada Pembelajaran Kompetensi Perakitan Dan Pemasangan Sistem Rem. Jurnal PTM Volume 9, NO. 2, 71-72, 2009. 
movements as they evaluate it personally because their actions that they carry out will be assessed by their students. b) Easy to prepare and implement. The method is easy to carry out since it only be done by conveying and mastering the material, where all teachers can implement this method. If the material presented is highly interesting, then the students will continue to linger to listen because they are carried away by the atmosphere of the material. c) More economical in terms of time: The same as the discussion above, it only needs to prepare the material as well as possible so that when it is explained, it does not feel that time will run out, even though sometimes the new material only explained until the middle of the discussion. Therefore, this is an advantage of the lecture method, which is very preferred by the teachers.

d) Can use broad lessons: Using the lecture method is not only required to master one material from each lesson. As a teacher, in explaining the material, it must be related to other lessons because, in this way, the range of knowledge that students will have will be wider. e) Help students to listen more accurately, critically and attentively: Exploring the material is very essential for both teachers and students because it will cause students to ask questions continuously because of their curiosity. Besides, it can be a medium to exchange ideas with their teachers and other friends because of the broad knowledge. In this context, the lecture method does not only have advantages, but there are also disadvantages as well. In this case, it is very common to occur everywhere. The disadvantages of the lecture method include:

The frequent use leads to boredom: Indeed, the frequent use of this lecture method often makes the listeners feel bored. Therefore, being teachers require someone to master other methods as well, so that when delivering the material, it can be maximized according to the method the teachers want to use. Difficult to perceive student understanding: In this case, it is a highly difficult situation for a teacher. It is because when the teachers finish explaining the material, they will certainly ask their students if they already understand what was said earlier. Many of the students will definitely answer that they understand. It sometimes makes the teachers do not understand what the students feel and when given questions, sometimes some of them still cannot answer as well. Do demonstration resulting in verbalism: It is essential that when the teachers delivering the material, there needs to be a demonstration. Sometimes the teachers forget to do it. Some teachers also just sit quietly by explaining the material but does not show an expression towards their students. It makes the students give a less good assessment towards the teacher. Making the students passive: students' boredom is also influenced by the method used by the teachers. Moreover, the lecture method for students is really boring and therefore, there is the need to provide a real education for students and it must be able to melt the situation so that conditions run conducive again.

One thing to note when using the lecture method is the initial stage of preparing, that must be as careful as possible, starting from the purpose of using this method and mastering the points of each material and having equipment so that it can be maximally possible later. This lecture method can be successful if it is supported by other methods in its use, for instance, mixed with question and answer method, discussion method, or others. It will make the lecture method more interesting for students to listen ${ }^{12}$.

12 Widiyati, A.. Metode Mengajar Sebagai Strategi Dalam Mencapai Tujuan Belajar Mengajar. Jurnal Pendidikan Akuntansi Indonesia, Vol 3 no 2, 2014, 67-68. 
Education has its values in addition to changing the competencies of students as stipulated in Law No. 20 of 2003 which regulates the National Education System in Chapter II Article 3, stipulating that education has an objective which is: "The function of the National education is to provide a change of competence and form a good personal character, an intelligent nation and become a dignified nation. All of which aims to make students have good morals, piety and have faith in Allah SWT, competent, physically and mentally healthy, independent, creative and can be a responsible and fair nation." Based on the objectives of national education, the orientation of education does not only focus on aspects of knowledge but also aspects of attitude and expertise.

Therefore, educators are required to encourage change in students in terms of attitudes and behaviour, both towards others or to Allah SWT. In accordance with the law that has regulated this matter, the lessons of Aqeedah Morals have more meaning in the form of knowledge, which is not only collected but also to be practised in daily life like how to be convinced, fear, and believe in Allah SWT and have good morals. Besides, the learning of Aqidah Morals can internalize Islamic values to students, which are evidence of the success of the learning.

It becomes problematic in learning of Aqeedah Morals which is one of the subjects that have very significant values and must be taught to students appropriately and correctly. These subjects are an interrelated unity so as to make humans as Khalifah on earth who are created by Allah SW'T to be leaders and provide good change to creatures on earth. Besides, the lesson contains vertical and horizontal human relationships. Therefore, this subject must be implanted the heart and be practised directly and istiqomah in students' daily lives. It has become one of the responsibilities of the educators to be able to present the subject and become one of the students' favourite subjects so that it is easy to help change student attitudes. The educators must be able to analyse massively to make Aqeedab Moral learning can get into the soul of the students ${ }^{13}$.

This subject is the main demand in education and is involved in the objectives of developing Islamic education which refers to the curriculum of character education. It becomes an essential point to build a good nation as well. This character education is implemented with a good learning strategy. Character education is a curriculum that becomes the unit level in education which becomes the basis of material ${ }^{14}$.The way to implement it is by implanting a strong aqeedah in students so that they are not easily drifted by the world currents which are becoming worse and mixed with western ideologies that will change our aqeedah as Muslims.

Therefore, taking the experience of one of the teachers named Munawarah that "The objective in particular, so that the material delivered by the teachers can be in harmony with the syllabus that can be understood, and practised in daily life, including in the school environment, family and surrounding areas. Regarding the morals, from aqeedab to morals, it

13 Barat, J. (n.d.). Penerapan Model Role Playing dalam Pembelajaran Aqidah Akblak. The Implementation of Role Model in Aqidah Akblak Learning Dudun Najmudin Sekolah Tinggi Agama Islam ( STAI) Syamsul 'Ulum Gunungpuyuh I .01, 28-43, 2016.

14 Machin, A., Implementasi pendekatan saintifik, penanaman karakter dan konservasi pada pembelajaran materi pertumbuhan. Jurnal Pendidikan IPA Indonesia, 3(1), 28-35. https://doi.org/10.15294/jpii.v3i1.2898, 2014. 
implies that if the implanting of aqeedab is strong, then the morals will be good, and vice versa. If the knowledge and implanting of aqeedah are weak, then the morals will also be weak. Therefore, the most important and the key to good morals is a strong aqeedah. It means that morals follow aqeedah. Besides, in assigning their duties in the material of aqeedab morals, the teachers must be able to answer the new trends so that the students can respond to this and can be matured. It must be considered in terms of affective, cognitive and psychomotor. Therefore, in its development, it can improve quality and have a role and strength in strategic positions in learning ${ }^{15}$.

The method is a way or technique used by the teachers in delivering lessons. Methods can involve approaches or strategies used to deliver material that supports learning goals. In the selection of a method, it must consider the ability of teachers to implement it, the students' condition, the state of the learning environment, and its suitability with the objectives and learning materials. Active learning methods that can instil and develop democratic attitudes in students is called the role-playing method. The role-playing method can be used by PPKn teachers to instil democratic attitudes in students ${ }^{16}$.

The role-playing method has advantages in instilling democratic attitudes. The roleplaying method is a method used to explore the feelings of students, transfer and embody views about the behaviour, values, and feelings of students, develop behavioural problemsolving skills and explore the subject matter with different ways to develop democratic attitudes in dealing with problems ${ }^{17}$.

The role-playing method is a way of assigning lesson materials by developing the imagination and appreciation of students. The development of imagination and appreciation is done by students playing themselves as living figures or inanimate objects. This play is commonly performed by more than one person, depending on the role they played. In the role-playing strategy, the emphasis is on emotional involvement and sensory observation in a problem situation that is actually faced. The students are required as learning subjects who actively engage in language practices (asking and answering) together with their friends in certain situations. The Role-Playing Strategy is also organized based on heterogeneous groups of students. Each group demonstrates or performs a scenario that has been prepared by the teacher. The students are given the freedom to improvise, but still within the limits of the scenario from the teacher. From the understanding that has been explained, it can be concluded that role-playing is a learning method that can be done by two or more students where students interact by playing roles based on a scenario that has been prepared by the teacher, but students can improvise within reasonable limits ${ }^{18}$.

15 Kamal, F. Strategi Inovatif Pembelajaran Akidah Akhlak Di Man Wonosobo Jawa Tengah. Jurnal Penelitian Dan Pengabdian Kepada Masyarakat UNSIQ, 4(1), 45-55, 2017.

16 Subhekti, f., Asran, M., \& Ali, M. (n.d.). Peningkatan Aktivitas Belajar Menggunakan Metode Diskusi Pada Pembelajaran Pkn Kelas v sdn 07 Kembayan. Jurnal Pendidikan dan Pembelajaran, 3(4), 1-15, 2010.

17 Haryono, D., Lompat, T., Jauh, L., \& Jongkok, G. Jurnal Wahana Pendidikan Issn 2355-242. 5, 1-9, 2018.

18 A, D. R. Saudara Dan Teman. 4(1), 35-49, 2018. 
The steps to use the Role Playing method according to Siberman are ${ }^{19}:$ 1) Make a role play where you will demonstrate the desired behaviour, such as receiving guests properly. 2) Inform the class that you will play the main role in playing this role. The work of students is to help you deal with the situations. 3) Ask the students to play the role of being someone else in the situation. (for example, being a guest and host). 4) Give students the opening notes to read to help or bring into the role. 5) Start the role-playing, but stop at frequent intervals and ask the class to give you feedback and direction as the scenario progresses. 6) Don't hesitate to ask students to give you a special line to use, for example, at a special point, ask, "what should I say next?" 7) Listen to the suggestions from the audience and try to practice. 8) Continue the role-playing until students increasingly train you to handle the situation. This gives them skills training when you do the actual role for them.

In various learning methods available, surely there are advantages and disadvantages. Not all methods are good nor bad, so the Role Playing method has advantages that can be used by a teacher, according to Roestiyah among others $\operatorname{are}^{20}:$ a) Students are more interested in paying attention during the learning process. b) Train students to be active in the learning process. c) Develop a sense of responsibility for the role they played. d) Students will be trained to take initiative and be creative. d) Students' spoken language can be fostered into a good language so that it is easily understood by others ${ }^{21}$.

After looking into the advantages, it is also necessary to look into the disadvantages of the Role Playing method so that the Aqidah Akhlak teachers can understand very well as the preparation in dealing with students in the class. The disadvantages of the role-playing method are: 1) If the teacher does not understand the steps in implementing this strategy, it will disrupt the ongoing role-play activities. 2) It takes some time. 3) Most students who do not participate in role-playing become less active. 4) It requires a large place. 5) Other classes are often disturbed by the sound of the cast and audience ${ }^{22}$.

This can be seen when students take part in teaching and learning activities in class, where students are active, students have more respect on the opinions of their friends, there is a tolerance, respect the opinions of friends, cooperate when making presentations, more confident when performing their roles based on the characters in the scenario, and be more creative in developing roles that they played and can implement those roles in the classroom environment. Furthermore, the students get a variation in teaching and learning activities to increase an understanding of students who can finally behave based on democratic values ${ }^{23}$.

In the implementation, there is a method known as the picture method. This method is a learning model that uses pictures posted in front of the class and the teacher asks students one by one to explain or describe the picture according to each of them. The steps to use this method are: first, the teacher must prepare or make a lesson plan. Second, the teacher

19 Siberman, M. Pembelajaran Aktif. Kuala Lumpur: Institut Terjemahan Negara Malaysia Berhad, 2009.

${ }^{20}$ Roestiyah, N. K, Teaching and Learning Strategies. Jakarta: PT Rineka Reserved, 2008.

${ }^{21}$ Zammi, M., Susilaningsih, E., \& Supardi, K. I, Jurnal Profesi Keguruan., 4(1), 37-41, 2018.

${ }^{22}$ Roestiyah, N. K, Teaching and Learning Strategies. Jakarta: PT Rineka Reserved, 2008.

23 Nurhidayati, S., Zubaidah, S., \& Indriwati, S. E. Pengaruh Metode Inkuiri Terbimbing Terhadap aktivitas Dan Hasil Belajar Biologi Siswa. Jurnal Kependidikan, 14(3), 285-294, 2015. 
prepares several methods such as lectures, discussions, and pictures. Third, by using the media or learning resources needed such as LCDs, projectors, books, and display material in the form of images. Fourth, prepare evaluations in the form of worksheets given by the teacher to students. The advantages of this method are: 1) The teacher will better know the abilities of each student. 2) It can train students to think critically. 3) The lesson looks more interesting so the students feel happy and comfortable with the lesson. 4) The teacher feels helped with this $\operatorname{method}^{24}$.

It is very clear that the word picture means a picture or image. This picture method makes the teacher has a tool in the form of pictures to facilitate the understanding of students, this method is an innovation in learning that uses students' visualization. Further, this method also has disadvantages, namely: 1 . Time-consuming, 2 . Fear will cause a commotion in the classroom or different opinions between the students will cause commotion in the classroom, 3. Some students do not want or are difficult to express their opinion, 4. This method will not run smoothly if the facilities are inadequate or unsupportive ${ }^{25}$.

\section{CONCLUSION}

Aqidah Akblak is an easy lesson but it needs a good method to convey the values contained in it so that it can be useful and can be practised by students in their daily life so that it becomes a self-foundation that will never fade. It must also use a good strategy and interesting in delivering the lesson. One of the methods in learning Aqidah Akblak is to use the Role-Playing learning method. By using this method students can understand the real attitude of the material they have acquired and how to respond when there is an incident. In this case, a teacher must understand the methods that will be delivered to realize the objectives to be achieved. In addition to providing material, a teacher is also required to be able to give examples of good behaviour outside the classroom as a form of realization of the knowledge or teaching that has been conveyed.

\section{ACKNOWLEDGEMENT}

Thank you to the Muhammadiyah University Yogyakarta for their support in this research, with various facilities that have been provided to us in the form of libraries, internet access, and access to various national and international journals so that this research can be completed in a maximum and timely manner.

24 Kelas, S., Di, I. V, \& Bawan, M. I. N. (2017). Penggunaan strategi role play dan strategi modeling the way dalam pembelajaran aqidah akblak terhadap hasil belajar siswa kelas iv di min bawan barabai. VII, 167-196, 2017.

25 Shaffat, I., Strategy, O. L., Hamid, S., \& Edutainment, M. Jurnal Ilmiah Mandala Education 81. 3 (2), 8198, 2017. 


\section{REFERENCES}

A, D. R. Saudara Dan Teman. 4(1), 35-49, 2018.

Barat, J. (n.d.). Penerapan Model Role Playing dalam Pembelajaran Aqidah Akblak The Implementation of Role Model in Aqidah Akblak Learning Dudun Najmudin Sekolab Tinggi Agama Islam ( STAI ) Syamsul 'Ulum Gunungpuyuh I . 01, 28-43, 2016.

Haryono, D., Lompat, T., Jauh, L., \& Jongkok, G. Jurnal Wahana Pendidikan Issn 2355-242. 5, 1-9, 2018.

Harsono, B. Perbedaan Hasil Belajar Antara Metode Ceramah Konvensional Dengan Ceramah Berbantuan Media Animasi Pada Pembelajaran Kompetensi Perakitan Dan Pemasangan Sistem Rem. JURNAL PTM VOLUME 9, NO. 2, 71-72, 2009.

H., \& Purwati, A. Implementasi Kurikulum 2013 Pada Mata Pelajaran Aqidah Akhlak Bagi Siswa Kelas VIII Di Madrasah Tsanawiyah Nurul Hikmah Barupring. Jurnal Sekolah Dasar, 3(1), 47-59. https://doi.org/10.36805/jurnalsekolahdasar.v3i1.410. 2018.

Kamal, F. Strategi Inovatif Pembelajaran Akidah Akhlak Di Man Wonosobo Jawa Tengah. Jurnal Penelitian Dan Pengabdian Kepada Masyarakat UNSIQ, 4(1), 45-55, 2017.

Kelas, S., Di, I. V, \& Bawan, M. I. N. Penggunaan strategi role play dan strategi modeling the way dalam pembelajaran aqidah akblak terhadap hasil belajar siswa kelas iv di min bawan barabai. VII, 167196, 2017.

Machin, A. Implementasi pendekatan saintifik, penanaman karakter dan konservasi pada pembelajaran materi pertumbuhan. Jurnal Pendidikan IPA Indonesia, 3(1), 28-35. https://doi.org/10.15294/jpii.v3i1.2898, 2014.

Mahmudah, M. Urgensi Diantara Dualisme Metode Pembelajaran Ceramah Dalam Kegiatan Belajar Mengajar Untuk Siswa MI/SD. Cakrawala: Jurnal Studi Islam, 11(1), 116-129. https://doi.org/10.31603/cakrawala.v11i1.107, 2016.

Mansir, F. Diskursus Sains dalam Kurikulum Pendidikan Agama Islam di Sekolah dan Madrasah Era Digital. Kamaya: Jurnal Ilmu Agama, 3(2), 144-157, 2020.

Mansir, F., Purnomo, H., \& Tumin, T. PENERAPAN PEMBELAJARAN PENDIDIKAN AGAMA ISLAM BERBASIS SAINS BUDAYA LOKAL DI SEKOLAH DAN MADRASAH. TARBAWY: Indonesian Journal of Islamic Education, 7(1), 70-79, 2020.

Nurhidayati, S., Zubaidah, S., \& Indriwati, S. E. Pengaruh Metode Inkuiri Terbimbing Terhadap aktivitas Dan Hasil Belajar Biologi Siswa. Jurnal Kependidikan, 14(3), 285-294, 2015.

Purba, F. J. Meningkatkan Hasil Belajar Siswa Dengan Metode Demonstrasi. INPAFI (Inovasi Pembelajaran Fisika), 6(3), 83-91. https://doi.org/10.24114/inpafi.v6i3.11115, 2018.

Purwati, D., \& Nugroho, A. N. P. Pengembangan Media Evaluasi Pembelajaran Sejarah Berbasis Google Formulir di SMA N 1 Prambanan. ISTORLA: Jurnal Pendidikan dan Sejarah, 14(1), 2018.

Rem, P. S. Perbedaan Hasil Belajar Antara Metode Ceramah Konvensional Dengan Ceramah Berbantuan Media Animasi Pada Pembelajaran Kompetensi Perakitan Dan Pemasangan Sistem Rem. Jurnal Pendidikan Teknik Mesin, 9(2), 2009.

Roestiyah, N. K. (2008). Teaching and Learning Strategies. Jakarta: PT Rineka Reserved, 2008.

Siberman, M. Pembelajaran Aktif. Kuala Lumpur: Institut Terjemahan Negara Malaysia Berhad, 2009. 
Shaffat, I., Strategy, O. L., Hamid, S., \& Edutainment, M. Jurnal Ilmiah Mandala Education 81. 3(2), 81-98, 2017.

Subhekti, F., Asran, M., \& Ali, M. (n.d.). PENINGKATAN AKTIVITAS BELAJAR MENGGUNAKAN METODE DISKUSI PADA PEMBELAJARAN PKn KELAS V SDN 07 KEMBAYAN. Jurnal Pendidikan Dan Pembelajaran, 3(4), 1-15, 2010.

Widiyati, A. Metode Mengajar Sebagai Strategi Dalam Mencapai Tujuan Belajar Mengajar. Jurnal Pendidikan Akuntansi Indonesia, 67-68, 2004.

Yasir, M., \& Karlina, E. Pengaruh Model Pembelajaran Stad Terhadap Hasil Belajar Mata Pelajaran Akuntansi. Research and Development Journal Of Education ISSN : 2406-9744, 2(1), 53-65, 2015.

Zammi, M., Susilaningsih, E., \& Supardi, K. I. (2018). Jurnal Profesi Keguruan. Jurnal Profesi Keguruan, 4(1), 37-41, 2018. 